\title{
IMPACTS, PATTERNS, INFLUENCING FACTORS AND POLICIES OF FUELWOOD EXTRACTION IN WAY KAMBAS NATIONAL PARK, INDONESIA
}

\author{
Ari Rakatama* \\ Natural Resources Conservation Agency of Lampung, Indonesia \\ Received: 15 November 2013, Revised: 18 November 2015, Accepted: 20 November 2015
}

\begin{abstract}
IMPACTS, PATTERNS, INFLUENCING FACTORS, AND POLICIES OF FUELWOOD EXTRACTION IN WAY KAMBAS NATIONAL PARK, INDONESIA. Uncontrolled fuelwood extraction from conservation forest of Way Kambas National Park (WKNP) could threaten the existing forest. This paper studies the way to tackle the forest degradation in WKNP, with less negative impacts to the local people. Study was conducted by analysing existing data and maps of WKNP in terms of forest degradation, forest inventories, current policies, survey on how fuelwood is extracted, observation on fuelwood gatherers, fuelwood demand, and identification of further policy options. Results show that the most significant factors influencing the fuelwood extraction activity in WKNP are land ownership, followed by the distance to forest area, income level, the number of household members and age of household head. In the field, the fuelwood utilization is allowed by WKNP Authority, although it is formally forbidden.It was stated that fuelwood extraction in the area should be less than 2.89 ton/ha/year to maintain its sustainability, based on the mean WNKP forest tree annual increment. The fact shows that fuelwood extraction in WKNP reduces of forest biomass stock (1.06 tons/ha/year) and decreases species diversity index (from 3.05 to 2.45), species evenness index (from 1.06 to 0.91 ) and old-young tree ratio (from 1.29 to 1). Ecosystem quality reduction is mainly caused by destructive techniques in extracting fuelwood such as slashing, scratching cambium, and cutting trees. Therefore, recommended policy includes legalizing fuelwood extraction with restrictions, providing alternative fuelwood and other biomass energy resources outside WKNP, conducting preventive (establishing checkpoints and increasing patrols) and pre-emptive (educating and campaigning) efforts, collaborating with other stakeholders, and empowering local economy.
\end{abstract}

Keywords: Fuelwood, national park, forest extraction, deforestation, rural energy

DAMPAK, POLA, FAKTOR YANG BERPENGARUH, DAN KEBIJAKAN PEMANFAATAN KAYU BAKAR DI TAMAN NASIONAL WAY KAMBAS. Pamanfaatan kayu bakar dari butan konservasi, seperti Taman Nasional Way Kambas (TNWK), dapat mengancam keberadaan butan apabila dilakukan tanpa kontrol yang baik. Tulisan ini mempelajari cara mengatasi degradasi butan di TNWK, dengan dampak negatif minimal bagi masyarakat lokal. Metode penelitian meliputi analisis data dan peta TNWK terkait dengan degradasi butan, inventarisasi, analisis kebijakan saat ini, survei pengambilan kayu bakar, pengamatan terbadap pengumpul kayu bakar, survei permintaan kayu bakar, dan identifikasi piliban kebijakan selanjutnya. Hasil penelitian menunjukkan bahwa faktor yang paling signifikan mempengarubi aktivitas ekstraksi kayu bakar di TNWK adalah kepemilikan tanah, diikuti oleh jarak. ke kawasan butan, tingkat pendapatan, jumlah anggota rumah tangga, dan usia kepala rumah tangga. Aktivitas pemungutan kayu bakar ini terjadi di kawasan TNWK, meskipun dilarang oleh peraturan formal di tingkat nasional, sehingga prinsip pengambilan kayu bakar secara berkelanjutan harus kurang dari 2,89 ton/ ha/tabun (pertumbuban rata-rata tabunan butan TNWK dalam kondisi normal). Fakta dilapangan menunjukan babwa pengambilan kayu bakar di TNWK menurunkan stok biomasa butan (1,06 ton/ha/tahun) dan menurunkan indeks keanekaragaman jenis (dari 3,05 menjadi 2,45), indeks kemerataan jenis (dari 1,06 menjadi 0,91), dan rasio pohon-permudaan (dari 1,29 menjadi 1). Penurunan kualitas ekosistem disebabkan karena penggunaan teknik. yang merusak seperti meranting, menderes, dan menebang. Oleh karena itu,

*Corresponding author: ari_raka@yahoo.com 
beberapa pilihan kebijakan yang direkomendasikan adalah melegalisasi pengambilan kayu bakar dengan batasan-batasan tertentu, menyediakan sumber alternatif kayu bakar dan energi biomassa lain di luar kawasan TNWK, melakukan upaya pencegaban (mendirikan pos-pos pemeriksaan dan meningkatkan patroli) dan pre-emptive (mendidik dan berkampanye), bekerja sama dengan pemangku kepentingan lainnya, dan memberdayakan ekonomi lokal.

Kata kunci: Kayu bakar, taman nasional, ekstraksi hutan, deforestasi, energi pedesaan

\section{INTRODUCTION}

Fuelwood has been used since the ancient centuries, and until now it is still an important source of energy at many places. Global demand for fuelwood might even increase in the future based on the fact that most European Union countries increase their biomass consumption as a renewable source of energy for power and heat plants (Verhoest \& Ryckmans, 2012). In Asia, the number of people rely on fuelwood is about 1.711 billion people and is predicted to increase to 1.733 billion in 2030 (Organisation for Economic Co-operation and Development, 2002). Accordingly, about 1.5016 billion cubic meters per year of fuelwood are needed to fill the need of fuel energy globally. The main fuelwood used countries are located in Africa, South America, South Asia, East Asia, and Southeast Asia (Broadhead, Bahdon, \& Whiteman, 2001). In South Korea, the use of biomass as a portion of renewable energy is predicted to increase from $6 \%$ to more than $30 \%$ by 2030 (Chanal, 2012). In Indonesia, around $47.71 \%$ or about 26.2 million household rely on fuelwood and generally live in rural areas (Department of Forestry, 2005). Although recently these household have begun to use Liquid Petroleum Gas (LPG) and electricity, fuelwood demand remains high, particularly in the areas close to forest with low accessibility for modern energy sources (Arnold, Kohlin, Persson, \& Shepherd, 2003).

Supply of fuelwood in Indonesia comes from non-forest area $(65 \%)$, from production forest area (6\%), and about $29 \%$ from unknown sources (Arnold et al., 2003). Conservation forest areas such as national parks that are adjacent to villages then become also source of fuelwood for the local people although it is illegal. The $29 \%$ supply of fuelwood mentioned by Arnold et al. (2003), might then partly comes from conservation forest areas. Way Kambas National Park (WKNP) in Lampung Province which is surrounded by 37 villages with around 34,000 household (WKNP Authority, 2011) has become the source of fuelwood for the local people.

Without a good control, fuelwood extraction from conservation forest can threaten the forest's existence. Simon (1999) stated that in areas dominated by community uses, forest destruction usually begins with fuelwood extraction, followed by illegal logging and finally by forest occupation. As one of the influencing factors for the destruction of conservation forests, fuelwood extraction should then be controlled. The aim of this research is to find appropriate solutions to avoid further forest degradation in WKNP, without negative impacts on the well-being of the local people who use the fuelwood, including recommendations for an appropriate policy on fuelwood extraction, based on the understanding of the impacts, patterns, influencing factors and the existing policies of fuelwood extraction in WKNP.

\section{MATERIAL AND METHOD}

\section{A. Research Site Selection}

The research was conducted at Way Kambas National Park in Lampung Province, Indonesia and its adjacent villages from April to August 2013. Data were collected using forest inventory method at three different locations of WKNP forest, namely: (1) forest area located more than $5 \mathrm{~km}$ from the border of Labuban Ratu VI Village, (2) forest area that is directly bordered with Labuhan Ratu VI Village, and (3) forest area that bordered with Rantan Jaya Udik II Village. The first location was chosen because there was no villager activity in the area. The 
second location was chosen because Labuhan Ratu VI is located next to the office of WKNP and forest ranger, and the villagers are allowed to enter WKNP area for fuelwood gathering only under control of forest rangers. Rantau Jaya Udik II village is located far from WKNP office, so it was selected due to limited access of forest rangers to the area. Villagers from Rantau Jaya Udik II entered WKNP forest area not only for collecting fuelwood, but also for grazing animal, farming, logging, hunting, and fishing. Thus, it is presumed that the forest near this village is degraded due to various activities. Data were also collected using socio-economic survey at Labuban Ratu VI Village which was selected due to its location that near WKNP and forest rangers offices.

\section{B. Data Collection and Analysis}

To understand the impacts of fuelwood extraction, forest inventories and data collection were conducted in three different conditions of WKNP forest (the forest area with no villager activity; the degraded forest area due to fuelwood extraction only; and the degraded area due to mixed activities). A pilot survey was conducted in each location to calculate required sample size. Three plots were selected randomly as preliminary samples. Figure 1 was an example of typical plots for forest inventory at the tropical woodlands (Verplanke \& Zahabu, 2009):
$\mathrm{n}=\frac{\mathrm{CV}^{2} \times \mathrm{t}^{2}}{\mathrm{E}^{2}}$

Where:

$\mathrm{n} \quad=$ sample size

$\mathrm{CV}=$ coefficient of variation which was the measure of variability of tree crosssectional area at breast height

$\mathrm{t}=$ expression of confidence that the true average was within the estimated range. For three plots this always had a value of 2.353

$\mathrm{E}=$ error that you were willing to accept in the final estimation

Number of sample size depended on the coefficient of variation of the three plots invented in the pilot survey in each location. There were six required plots in the first location, ten plots in the second location and 16 plots in the third location that were spread out evenly over the whole area in each forest location. The data were then used to measure the biomass in each forest location by using equation as below (Brown et al., 1989):

$\mathrm{y}=\exp \left[-3.1141+0.9719 \ln \left(\mathrm{D}^{2} \mathrm{H}\right)\right]$

Where:

$\exp [\ldots]$ means "raised to the power of $[. .]$.

$\mathrm{y}=$ above-ground biomass in $\mathrm{kg}$

$\mathrm{H}=$ height in $\mathrm{m}$

$\mathrm{D}=$ diameter in $\mathrm{m}$, at breast height $(1.3 \mathrm{~m})$

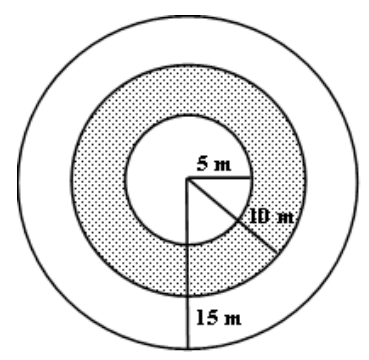

Figure 1. Sample plot of forest inventory

Remarks: Mixed activities are the activity of villagers that enter WKNP not only for extracting fuelwood, but also for grazing animal, farming, logging, hunting, and fishing.

- Within 5 m radius: inventory of saplings (young trees with $\mathrm{DBH}$ less than $10 \mathrm{~cm}$ )

- Within 10 m radius: inventory of poles (trees with DBH between $10 \mathrm{~cm}$ and $20 \mathrm{~cm}$ ).

- Within $15 \mathrm{~m}$ radius: inventory of trees with DBH more than $20 \mathrm{~cm}$ 
This equation was developed to estimate the weight of vegetation based on dimensional measurement (height and diameter). It was effectively applied in the area with annual rainfall from 1,500 to 4,000 $\mathrm{mm}$ (Brown et al., 1989) such as in WKNP forest.

In calculating the rate of forest biomass stock reduction and mean annual increments, some information based on interview with key informants were used as the base line. The information were: (1) the forest age in the three locations invented was approximately 30 years, because the existing forest was a secondary forest resulted from reforestation in 1980's where the original forest in these locations were completely destroyed by logging concession activity, forest occupation, and forest fire, (2) people surrounding the locations had invaded WKNP for fuelwood since approximately 8 years ago, because there was not enough fuelwood sources in the village and the forest resulted from the reforestation was now mature enough (approximately 22 years old) for fuelwood sources. Estimation of the mean annual increments and forest biomass stock reduction in this research was done as follows:

1) Mean annual increments $=$ Current forest biomass stock/Forest age. (Mean annual increments calculation was only valid for forest in normal condition or no villager activity).

2) Forest biomass stock when fuelwood extraction start $=$ Mean annual increment $*$ Forest age when fuelwood extraction start

3) Forest biomass stock reduction $=$ Forest biomass stock when fuelwood extraction start - Current forest biomass stock

4) Rate of forest biomass stock reduction $=$ Forest biomass stock reduction / Time of fuelwood extraction

Observation and comparison of the data in the three locations were arranged by comparing the species number found ( $\mathrm{SN}$ ), the diversity index (Ludwig \& Reynolds, 1988), the evenness index (Magurran, 1988), and the ratio between trees and saplings (OYR).

Survey on how fuelwood was extracted and the fuelwood demand was conducted to understand the patterns and the influencing factors of fuelwood extraction in WKNP forest. Samples were selected randomly (Black, 2008) and the sample size was calculated by using statistical equation (Yamane, 1967) as follows:

$$
\mathrm{n}=\frac{\mathrm{N}}{\left(\mathrm{N} \cdot \mathrm{d}^{2}\right)+1}
$$

Where:

$\mathrm{n}=$ sample size

$\mathrm{N}=$ population size

$\mathrm{d}=$ precision/critical value assigned 10\% (0.1) for the $95 \%$ level of confidence

In the survey on fuelwood extraction, 80 respondents (fuelwood gatherers) were divided in two groups ( 32 professional and 48 subsistence gatherers). The division was conducted to understand the differences of fuelwood extraction pattern between the two groups. The population size of professional gatherer was 347 people and subsistence gatherer was 524 people. All respondents were interviewed by using questionnaires. Then, 15 respondents (six professional and nine subsistence gatherers) were chosen as key informants by purposive sampling and snowball sampling based on the criteria that each key informant must had enough knowledge, ability and willingness to help in answering the research question (Verschuren \& Doorewaard, 2010). These key informants were lent GPS devices to record their tracks from their houses to WKNP forest area where they collected fuelwood. The data were then used to map the movement of fuelwood gatherers. Eighty women in the families were interviewed by using questionnaires to collect data on fuelwood demand. Housewives were chosen because mostly they were the direct users of fuelwood and knew exactly the fuelwood consumption for their families. Sampling method was conducted by systematic random sampling. All data gathered from this survey were analysed by variance analysis and multiple linear regression analysis.

Current policies on fuelwood extraction 
Table 1. Biomass measurement in the three different forest conditions of WKNP Forest

\begin{tabular}{lccc}
\hline \multicolumn{1}{c}{ Label } & $\begin{array}{c}\text { No villager } \\
\text { activity }\end{array}$ & $\begin{array}{c}\text { Fuelwood } \\
\text { extraction }\end{array}$ & $\begin{array}{c}\text { Mixed } \\
\text { Activities }\end{array}$ \\
\hline Number of sample plots & 6 & 10 & 16 \\
Current forest biomass stock (tons/ha) & 86.74 & 55.11 & 10.85 \\
Forest age (year) & 30 & 30 & 30 \\
Mean annual increments (tons/ha/year) & 2.89 & - & - \\
Forest age when fuelwood extraction start (year) & - & 22 & 22 \\
Forest biomass stock when fuelwood extraction start (tons/ha) & - & 63.58 & 63.58 \\
Time of fuelwood extraction (year) & - & 8 & 8 \\
Forest biomass stock reduction in 8 years (tons/ha) & - & 8.47 & 52.73 \\
Rate of forest stock reduction (tons/ha/year) & - & 1.06 & 6.59 \\
\hline
\end{tabular}

in WKNP were reviewed and analysed. Information and data were collected by interviewing 10 key informants representing top management of WKNP (1 person), forest rangers ( 2 people), WKNP staff ( 2 people), local people ( 3 people), and village leaders ( 2 people). Purposive sampling was chosen to ensure that every key informant had rich information to answer the research question (Verschuren \& Doorewaard, 2010). Then, qualitative method of data analysis was chosen in this study. The analysis was started during the data collection and/or after a certain period of the data collection where during the interview, the researcher started to conduct the data analysis of the responses obtained from the interview. Cross check with the triangulation method was also done to avoid any bias in the research results by analysing the data from multiple sources such as interviews, observations and documents (Cresswell, 1994).

\section{RESULT AND DISCUSSION}

\section{A. Fuelwood Extraction Impacts}

Table 1 reveals that fuelwood extraction activity led to the reduction of forest biomass stock. In the location with only fuelwood extraction activity, forest biomass stock declines from 63.58 tons/ha to 55.11 tons/ha in 8 years or the rate of forest biomass stock reduction in this location is about 1.06 tons/ha per year.
The reduction of forest biomass stock is much higher in the location with mixed activities. The forest lost its stock by 52.73 tons $/$ ha in 8 years period or 6.59 tons/ha per year. Complete information about the forest biomass stock calculation can be found in Appendix 1.

The natural forests of the three research locations have the same vegetation characteristics before they are destroyed by logging concessions. This is because the three locations are in the same forest region. Furthermore, reforestation programs in the locations grow new vegetation that are similar to natural vegetation.

Based on Table 2, in the location with no villager activity, old trees have high species diversity (3.05), followed by young trees with medium diversity (2.40). Old trees also have higher evenness index (1.06) than young trees (0.91) with old-young tree ratio of 1.29 . This indicates that the forest is in recovery phase from secondary forest to primary forest. Meanwhile, surrounding Labuban Ratu VI Village where only fuelwood extraction occurred, young trees have a slightly higher species diversity index (2.50) than old trees (2.45) although both still have medium diversity. Furthermore, the evenness index of the two vegetation levels in this location is nearly the same with old-young tree ratio of 1 . This also indicates that the forest still in the improvement stage to primary forest. 
Table 1. Diversity index, evenness index and old-young tree ratio in the three different forest conditions of WKNP

\begin{tabular}{|c|c|c|c|c|c|c|c|c|c|c|c|c|}
\hline \multirow{2}{*}{$\begin{array}{l}\text { Vegetation } \\
\text { Level }\end{array}$} & \multicolumn{4}{|c|}{ No villager activity } & \multicolumn{4}{|c|}{ Fuelwood Extraction Only } & \multicolumn{4}{|c|}{ Mixed Activities } \\
\hline & $\mathrm{SN}$ & $\mathrm{H}^{\prime}$ & $\mathrm{E}$ & OYR & $\mathrm{SN}$ & $\mathrm{H}^{\prime}$ & $\mathrm{E}$ & OYR & SN & $\mathrm{H}^{\prime}$ & $\mathrm{E}$ & OYR \\
\hline $\begin{array}{c}\text { Old } \\
>0.2 \mathrm{~m} \\
\text { DBH }\end{array}$ & 18 & 3.05 & 1.06 & & 15 & 2.45 & 0.91 & & 2 & 0.23 & 0.33 & \\
\hline $\begin{array}{c}\text { Young } \\
<0.2 \mathrm{~m} \\
\text { DBH }\end{array}$ & 14 & 2.40 & 0.91 & 1.29 & 15 & 2.50 & 0.92 & 1 & 9 & 1.92 & 0.87 & 0.22 \\
\hline
\end{tabular}

Remarks: SN = Species number found; H’ = Diversity Index; E = Evenness Index; OYR = Old-Young Tree Ratio

Opposing the location with no villager activity, in mixed activities forest, old trees have lower diversity index (0.23) and evenness index (0.33) than young trees with 1.92 of diversity index and 0.87 of evenness index. Moreover, old-young tree ratio in this forest is 0.22 . This data show that fuelwood extraction only actually caused less forest degradation compared to mixed activities. This means that other activities such as grazing animal, farming, logging, hunting and fishing simultaneously caused more damage to the forest.

Table 2 also reveals that there are changes in forest conditions as a consequence of fuelwood extraction. In the old tree level, there is a significant decline in diversity from 3.05 in normal condition to 2.45 with fuelwood extraction only. Then, the index falls significantly to 0.23 in mixed activities. Furthermore, there is also a downward trend of evenness index from 1.06 in normal condition to 0.91 in fuelwood extraction only and it falls to 0.33 in mixed activities. However, for younger vegetation, there are upward trends in both diversity and evenness index from normal condition to fuelwood extraction only. These happened because more sunlight in more open forest with fuelwood extraction stimulates the invasion of new species and the growth of seedlings, so this increases the diversity and evenness index. Meanwhile, old-young tree ratio decreases from 1.29 in normal condition to 1 in the location with fuelwood extraction only, and it declines to 0.22 in mixed activities.

In the long term, these changes will transform the structure of forest ecosystem and the vegetation including wildlife condition inside such as birds and insects. These findings are congruent with several previous studies stating that fuelwood extraction can generate forest degradation (Skutsch \& Ghilardi, 2008), slow plant productivity and forest regeneration (Sankaran \& McNaughton, 2005). This will lead to substantial changes in forest ecosystem as a result of the changes in vegetation structure, diversity, and composition (Mehta, Sullivan, Walter, Krishnaswamy, \& DeGloria, 2008), that could end in the reduction of biodiversity, particularly birds, reptiles and insects (Brown et al., 2010).

\section{B. Fuelwood Extraction Patterns}

The survey shows that most fuelwood gatherers, both professional and subsistence, collect dry and fallen twigs and branches. However, some of both professional and subsistence gatherers still conduct destructive techniques such as slashing green twigs and branches, scratching cambium and cutting the trees in extracting fuelwood. Due to this destructive fuelwood extractions, forest growth is disturbed significantly, because young trees cannot grow optimally and/or die. Thus, these practices trigger the reduction in forest biomass stock and mean annual increment of the forest. The changes of vegetation structure caused 
Table 3. Biomass measurement in the three different forest conditions of WKNP

\begin{tabular}{cccc}
\hline Label & $\begin{array}{c}\text { Subsistence } \\
\text { Gatherers }\end{array}$ & $\begin{array}{c}\text { Professional } \\
\text { Gatherers }\end{array}$ & $\begin{array}{c}\text { Professional- } \\
\text { Subsistence } \\
\text { Ratio }\end{array}$ \\
\hline The number of trip per year & 195 trips/year & 412 trips/year & 2.11 \\
The amount of fuelwood gathered per trip & $30 \mathrm{~kg}$ & $50 \mathrm{~kg}$ & 1.67 \\
The amount of fuelwood gathered per year & $5,840 \mathrm{~kg} /$ year & $20,580 \mathrm{~kg} /$ year & 3.52 \\
\hline
\end{tabular}

by these practices then also led to the changes in species diversity, species evenness and oldyoung tree ratio.

Table 3 shows that one professional gatherer could extract fuelwood about 3.52 times more than one subsistence gatherer in a year. Professional gatherers can also carry 1.67 more fuelwood in each trip compared to their counterpart, subsistence gatherers. One interesting fact in this table is that on average, a subsistence gatherer goes to WKNP forest around 195 trips per year or every 1-2 days. However, a professional gatherer could enter WKNP forest for fuelwood up to 412 trips per year. Since in a year is only 365 days, this indicates that a professional gatherer usually enter WKNP forest more than one time in a day. Most professional gatherers do not enter WKNP forest every day but irregularly. This means that professional gatherers usually decide one 'fuelwood gathering day' and they spend the whole day to extract fuelwood in WKNP forest. In a day, they could enter WKNP forest up to five times. This pattern is different from that of subsistence gatherers who usually spend only 1-2 hours in the forest every 1-2 days, usually after working on their farm land. Furthermore, motorcycle usage in transporting fuelwood is more often among professional gatherers compared to the subsistence gatherers. Considering these findings, professional gatherers tend to give more negative impacts than subsistence gatherers.

Moreover, by analysing the movement of the two gatherer groups, there is a tendency that WKNP area for fuelwood extraction in Labuban Ratu VI Village widens to the Southeast, avoiding the WKNP Offices in the North. The areas where the professional and subsistence gatherers extract the fuelwood in WKNP are different. Most subsistence gatherers enter WKNP forest from 0 to $1 \mathrm{~km}$. Meanwhile, the professional gatherers usually cross the WKNP border until $2 \mathrm{~km}$ depth. This is because professional gatherers need more fuelwood, so they have to go deeper than subsistence gatherers. Considering this fact, fuelwood extraction activity in this village should be anticipated by WKNP Authority as the starting point of the involvement of forest community in destructing conservation forest. Although it is not occurred yet in Labuhan Ratu VI, but it is possible when the location of fuelwood extraction is uncontrollable and far enough from the offices, people will start to do other illegal activities such as logging, grazing cattle, hunting, fishing and occupying forest.

\section{Influencing Factors for Fuelwood Demand}

Survey result shows that there are villagers in Labuban Ratu VI Village who extracted fuelwood from WKNP forest for commercial purposes, although most villagers use fuelwood for subsistence purposes. This should be anticipated by WKNP Authority since the need of fuelwood for commercial purposes will increase in the future following the growth of population and small scale industry surrounding WKNP. As stated by Arnold et al. (2003), population growth and economic growth (Mathews, 2009) in rural areas will increase the 
need and the consumption of fuelwood.

Spatial pattern analysis shows that the catchment area of WKNP forest is about two kilometer from WKNP border. People who live more than two kilometer from the WKNP border or outside the catchment area, usually looking for the closer sources of fuelwood such as plantations. From the map analysis of Labuban Ratu VI settlement, it can be estimated that about a half of the population in the village live near the WKNP, so that they depend on WKNP forest to fulfil their fuelwood needs. Number of household in Labuban Ratu VI Village is 798 household (Lampung Timur's BoS, 2010), so that can be assumed 399 families in the village looked for fuelwood at the WKNP forest area.

Result of survey shows that the average fuelwood demand of villagers surrounding WNKP is about $487 \mathrm{~kg} /$ household/month or about $5,840 \mathrm{~kg} /$ household/year. The fuelwood needs are fulfilled mainly from WKNP forest and in small amount $( \pm 10 \%)$ from backyards and gardens. So, it can be calculated that the total demand of fuelwood from WKNP forest in Labuhan Ratu VI is about 2,097.14 tons/year. If the mean annual increment of WKNP forest is 2.89 ton/ha per year, it is estimated that the needs of WKNP forest as fuelwood resources in Labuban Ratu VI is around 725.66 ha.

The calculation above does not include the population growth in Labuban Ratu VI which is around $8.44 \%$ per year in average from 2005 2010 (Lampung Timur's BoS, 2010) that will increase the fuelwood demand significantly in the future. The high number of population in Labuban Ratu IV is not only caused by birth rate but also by huge immigration of people from other areas. This means that the village is in transition or change from less to more developing village. In recent years many people especially from Java Island migrated to Labuban Ratu VI and other neighbouring villages seeking for farm land and/or working as labours at new established plantation companies (cassava and fruits) in the area.

The research result (Table 4) shows that land ownership is the most significant factor in influencing fuelwood demand. Villagers with sufficient land tend to collect fuelwood from their own land, but people with limited land have less fuelwood sources, so they have to go to forest to find fuelwood. This means that the need of WKNP area for fuelwood sources is unavoidable. Furthermore, other influencing factors for fuelwood demand are income level and the distance to forest area. Villagers with higher income have stronger purchasing power to pay modern energy sources such as gas and electricity. However, villagers with very low income only depend on free energy sources such as fuelwood. Villagers living very close to forest can easily go to forest to collect fuelwood anytime, but other villagers living far from forest tend to search fuelwood in closer sources such as backyards and gardens before deciding to go to forest.

This research also reveals that the number of household members is another influencing factor. This is because household with more member need more energy, so their demand for fuelwood is higher than smaller family. Last, this study states that age of household head can influence the fuelwood demand. The images of fuelwood as outmoded and impractical energy sources trigger young families to avoid fuelwood usage if they can afford modern energy sources such as gas and electricity.

\section{Existing Policy and Its Effectiveness}

In Forestry Act No. 41 of 1999, it is stated in article 50, paragraph $3 \mathrm{e}$, that everyone is forbidden to enter state owned forest and extract any forest product (including fuelwood) without right and licence. Anyone breaking this rule will be subjected to 10 years imprisonment or 5 billion rupiah fine (article 78, paragraph 4). However, the study shows that there is a contradiction between formal law at national level and the field implementation where fuelwood extraction is allowable because of humanitarian reason, limited capacity and lack of awareness on fuelwood extraction impacts. This condition is triggered by the exorbitant 
Table 4. Statistical examination results of the factors influencing fuelwood demand

\begin{tabular}{lccc}
\hline \multicolumn{1}{c}{ Variable } & Average & Significance & $\begin{array}{c}\text { Coefficient } \\
\text { Correlation }\end{array}$ \\
\hline Constant & & 0.001 & 5.29 \\
Distance to WKNP forest (X1) & 627 meter & 0.001 & -0.29 \\
Income level (X2) & Rp 6,328,090/year & 0.001 & -0.28 \\
Land ownership (X3) & 3,590 meter ${ }^{2} /$ household & 0.001 & -0.39 \\
Number of household members (X4) & 4 people/household & 0.006 & 0.05 \\
Education level (X5) & 3 (junior high school) & 0.111 & -0.02 \\
Age the head of the household (X6) & 43 years old & 0.029 & 0.14 \\
\hline
\end{tabular}

sanctions and lack of awareness of local people concerning the regulation and sanctions. However, allowing fuelwood extraction in WKNP forest could cause another problems. There is no clear regulations on how much fuelwood can be extracted, how often villagers can enter the park, which zone is allowable for fuelwood extraction, what extraction technique can be applied, for what purpose the extraction can be done. All these conditions cause the failure in maintaining sustainable extraction of fuelwood in WKNP.

\section{POLICY RECOMMENDATION}

\section{A. Legalizing Limited Fuelwood Extraction in WKNP Forest}

This policy aims to create a formal regulation to allow local people extracting fuelwood from WKNP forest. By legalizing fuelwood extraction in limited amount and making it explicitly, it is expected that WKNP Authority can control fuelwood extraction from the forest with better rules and regulations, clear guidelines and procedures, and defining clearly the party that is responsible for the policy implementation. In implementing this policy, the greatest challenge will come from the existing formal regulation at national level (Government Regulation No. 28 of 2011) stated that a national park can be used as energy sources (water, geothermal and wind) and for traditional utilization or own consumption by local people in the form of non-timber forest resource extraction. From this statement, the legality of fuelwood extraction in WKNP is in an unclear area. This is because the regulation does not state the utilization of biomass energy source from a national park. Therefore, fuelwood is not included as a source of energy that is allowed to be extracted from a national park. Furthermore, the regulation also stated that non-timber forest resource can be taken from the national park for traditional extraction (subsistence purposes). If fuelwood is considered as a timber forest product, then fuelwood collected from national park is considered as illegal. However, if dry and fallen twigs and branches are considered as nontimber forest resources, fuelwood collection in the form of dry fallen twig collection technique in utilization zone of the national park is legal. A successful policy then depends on this interpretation.

Besides wisely interpreting and implementing the regulation, legalization of fuelwood extraction in WKNP can be done by revising the existing government regulation; although, this is beyond the capacity of WKNP Authority, which is only an implementing unit of the higher institution, the Ministry of Environment and Forestry. However, WKNP Authority can advise the higher institutions through official 
letters, reports, and meetings. This step is not easy and needs a time as it will involve a long and complicated procedure to change the existing regulation, but it is possible.

WKNP Authority should control carefully the implementation of this policy especially the distortions that may occur in the field. It is very possible that the fuelwood gatherers still extract fuelwood by destructive techniques such as slashing, scratching cambium and cutting the trees. Furthermore, the legalization of fuelwood extraction may also trigger other illegal actions such as forest occupation, illegal hunting and logging in WKNP forest. Therefore, if this policy is implemented, it needs to have clearer regulations in terms of procedures and sanctions. In the implementation, the extraction zone/forest area, the maximum amount and frequency to collect and the cutting technique, must be regulated and controlled.

This policy should be implemented at WKNP level as a model to learn how the regulation impacts, before it is adopted nationally in all national parks in Indonesia. In order to ensure that the implementation of this policy stays on track, below are some suggested restrictions or regulations that might be appropriate:

1) Fuelwood extraction can only be done in the Utilization Zone of WKNP and it is permitted in national regulation. Utilization zone is the only zone in the national park that can be used for non-conservation purposes but without serious impacts to the whole ecosystem of the forest. The WKNP is divided into zones based on scientific studies. To ensure that local community know about this zone, it is needed to inform the villagers regularly about the natural and artificial borders of the zone as well as the purposes of the zone.

2) Fuelwood gathering technique is only allowed by collecting dry twigs and branches already fallen on the forest floor. It is forbidden to slash, scratch and cut the trees for fuelwood since it will disturb the forest ecosystem significantly.

3) Fuelwood gathering in WKNP is only for subsistence purposes (own consumption) of the local people, not for commercial purposes.

4) The amount of fuelwood taken from the forest must be less than 2.89 ton/ha per year (the mean annual increment of WKNP forest in normal condition). In practice, people must be restricted to take fuelwood no more than $15 \mathrm{~kg} /$ day/household. This number is based on the result of the survey on fuelwood demand where the actual need of fuelwood is around $487 \mathrm{~kg} /$ month/ household.

To run new policies above, some steps could be taken in the field by WKNP Authority:

1) Building checkpoints in strategic locations to check the amount of fuel-wood taken from the forest, especially in the main road used by villagers to access WKNP border.

2) Closing other roads and footpaths apart from the main roads with checkpoints.

3) Increasing forest ranger patrol along the border and inside the forest, especially to the direction of human invasion. This is to prevent fuel-wood gatherers go beyond the Utilization Zone and to do forbidden techniques in extracting fuel-wood.

In order to prevent offences, some fines should be prepared and well socialised to villagers. The fines should not be too high and unpayable by the villagers, but they have to be expensive enough to deliver deterrence. The fines should also consider the income level of the villagers and the degree of the offence. Based on the average income level of villagers, fines for different offences are proposed below:

1) $\mathrm{Rp} 1,000(\$ 0.13)$ per $1 \mathrm{~kg}$ exceeding the limit of fuel-wood extraction per day (17 $\mathrm{kg}$ ).

2) Rp 1,000,000 (\$130) for extracting fuelwood outside Utilization Zones of WKNP forest.

3) $\operatorname{Rp~} 10,000,000(\$ 1300)$ for extracting fuelwood by slashing green branches and twigs.

4) Rp 20,000,000 (\$2600) for extracting fuelwood by scratching cambium and cutting the trees. 
B. Providing Alternative Fuelwood and Other Biomass Energy Resources Outside WKNP

High demand for fuelwood is the drive of fuelwood extraction from WKNP. Introducing energy alternatives to fuelwood and/or creating other sources of fuelwood would reduce fuelwood extraction from national park area. These new resources must be closer and more accessible than WKNP forest, so that they will reduce the number of people going to WKNP forest for fuelwood. To realize these efforts, WKNP Authority can perform the following steps: (1) Optimizing the development of agroforestry systems in the villages especially in the farms, plantations, backyards, or other public lands that are allowed to plant fastgrowing wood species such as mangium (Acacia mangium) and albizia (Falcataria mollucana) as the alternative sources of fuelwood. This action is possible because there is still available land/ area at the villages around the WKNP; (2) Encouraging the villagers surrounding the WKNP to use the biomass energy sources such as rice husk, coconut shell and others through the process of socialization, counselling, education and training; (3) Providing enough area in the buffer zone of WKNP for fuelwood tree species plantation. Due to lack of budget and human resources of WKNP Authority, in the short term this policy may not be able to solve fuelwood extraction problem in WKNP, but in the medium and long terms, this kind of policy will synergize with other policies and contribute to the reduction of fuelwood extraction from WKNP forest.

\section{Preventive and Pre-emptive Efforts}

Preventive and pre-emptive efforts have slight differences. Preventive efforts focus on means of watching and controlling, while the pre-emptive effort is more focused on campaigning, raising awareness and educating activities. Both of these efforts have a common goal, i.e. to prevent and to reduce the amount of fuel-wood extraction which may affect WKNP forest negatively, especially extraction that uses scratching cambium and cutting techniques.

In the context of fuelwood extraction issues, there is no preventive and pre-emptive effort conducted by WKNP Authority nowadays. Therefore, one preventive action that should be conducted by WKNP Authority is building checkpoints in the strategic locations. Another preventive action is increasing forest ranger patrols along the borders of WKNP. These two preventive actions aim to reduce bad practices in extracting fuelwood. This policy is important since without this, the fuelwood gatherers will feel free to do anything in extracting fuelwood, including scratching cambium, cutting the trees and over extracting.

Furthermore, pre-emptive actions that can be carried out by WKNP Authority are educating and campaigning on the negative impacts of bad practices and over extraction of fuelwood. For example, fuelwood extraction by slashing, scratching cambium and cutting trees can trigger forest degradation, forest biomass stock reduction, and changes in species diversity, evenness, and old-young tree ratio where in the long term, these changes will transform the structure of forest ecosystem and the vegetation including wildlife condition inside such as birds and insects. The action should involve other stakeholders, especially NGOs and local government. Moreover, it is important to educate local people and to train cadres to support conservation measures amongst the villagers. To incorporate this policy into existing program at WKNP, the policy should be implemented together with (being the integral part of) preventive and pre-emptive actions aiming to reduce other illegal activities such as forest occupation, illegal hunting, logging, grazing cattle. Indeed, this will save the cost and resources in the implementation of this policy.

\section{Collaboration with Other Stakeholders}

WKNP Authority needs to collaborate with all stakeholders in order to produce synchronized and synergistic policies on the issues of fuelwood extraction in WKNP. This is 
because the issue is not only the responsibility of WKNP Authority, but also a complex problem associated with multiple stakeholders. Collaboration is absolutely necessary because there are many things must be done beyond the capacity of WKNP Authority such as:

1) Improving the distribution of commercial energy such as LPG and electricity to all villages surrounding WKNP in order to increase people's access to these energy sources. Key stakeholders include local government, Ministry of Energy, and corporates in the field of energy.

2) Increasing the production and distribution of more efficient fuelwood stoves in the villages surrounding WKNP. Key stakeholders incude local government, Ministry of Energy, Ministry of Industry and corporates in the field of energy and manufacture.

3) Improving transportation facilities to increase public access for other energy sources. Key stakeholders include local government, provincial government and corporates in the field of infrastructure.

4) Increasing villagers' income, to increase purchasing power of villagers to buy commercial energy sources. Key stakeholders included local government, provincial government, Ministry of Agriculture, Ministry of Industry, NGO and corporates in the field of finance, agriculture and manufacture.

5) Encouraging the use of agricultural waste as alternative biomass energy sources that can replace the role of fuelwood. Key stakeholders include local government, Ministry of Energy, Ministry of Agriculture, $\mathrm{NGO}$, and corporates in the field of energy and agriculture.

Indeed, the means above are beyond the capacity of WKNP Authority. However, it is possible to run by good coordination with all stakeholders. WKNP Authority needs to encourage the realization of the above means.

\section{E. Empowering Local Economy}

One of the most influencing factors in the extraction of fuelwood is income level. This factor has significant negative correlation to the level of fuelwood extraction where the lower the income level, the higher the level of fuelwood extraction. Based on this, efforts to increase villager's income level through economic empowerment are needed. The idea of economic empowerment to reduce fuelwood extraction is in line with Johannesen (2006) who stated that economic empowerment for people surrounding national park through the creation of jobs and stimulation of farming productivity will contribute to save conservation forest. The increased income will reduce the rate of fuelwood extraction because villagers may be able to pay commercial energy sources such as LPG and electricity. Economic empowerment efforts around WKNP can be done in several ways: (1) Involving and employing villagers in the development and management projects of WKNP, particularly in the area of work that does not require highly educated workforces, for example as porters, securities, merchants, and parking attendants; (2) Giving aid and assistance to villagers in the form of capital, farm equipment and training for human resources and capacity building; (3) Coordinating and synchronizing the community empowerment programs of WKNP with other stakeholders' program that are also responsible for the welfare of WKNP people such as Provincial Government, Local Government, private sector and NGOs.

Running preventive and pre-emptive efforts should be immediately implemented to prevent further degradation at WKNP. However, all policy options above should be run together since one policy will support another policy. In other words, the effectiveness and social impacts of one policy depend on the success of other policies. Some of the policies above, such as preventive and pre-emptive efforts, and economic empowerment, should not be run exclusively to address fuelwood issue, but be run together as an integral part of policy 
for other major issue in WKNP such as forest occupation, and grazing cattle. Indeed, this is to save the cost and resources in implementing the policy. In the end, this will increase the effectiveness and reduce the negative social impacts of the whole policy implementation.

\section{CONCLUSION}

This research concludes that fuelwood extraction in WKNP are influenced by surrounding community land ownership, the distance to forest area, income level, the number of household members, and age of household head. Although fuelwood extraction is forbidden by formal law at national level, in the field this activity is allowable which creates the failure in maintaining sustainable fuelwood extraction. This is supported by the fact that fuelwood extraction in WKNP triggers forest degradation, the reduction of forest biomass stock and the changes of species diversity, species evenness, and old-young tree ratio due to destructive techniques used such as slashing, scratching cambium and cutting trees. Therefore, some recommended policy options are legalizing limited fuelwood extraction, providing alternative fuelwood and other biomass energy resources outside WKNP, running preventive and pre-emptive measures, collaboration with other stakeholders and empowering local economy.

\section{ACKNOWLEDGEMENTS}

This paper is a part of theses written by the author when studied at University of Twente and Padjadjaran University. This research is funded by Pusbindiklatren Bappenas and Nuffic Neso Indonesia. We thank all field counter parts, Dedi Isnandar, Mardina Juniawan, Eko Ariyanto, Rudi Wawan, and Wilson for large support in collecting and analysing the data and all reviewers for their contributions.

\section{REFERENCES}

Arnold, M., Köhlin, G., Persson, R., \& Shepherd, G. (2003). Fuelwood revisited: what has changed in the last decade?. Occasional Paper No. 39. Bogor : Center for International Forestry Research.

Black, K. (2008). Business statistics for contemporary decision making. ( $5^{\text {th }}$ Edition). John Wiley \& Sons, Inc.

Broadhead, J., Bahdon, J., \& Whiteman, A. (2001). Wood-fuel consumption modelling and results. (Annex 2) in Past Trends and Future Prospects for the Utilization of Wood for Energy (No. GFPOS/WP/05). Rome.

Brown, G., Tolsma, A., Murphy, S., Miehs, A., McNabb, E., \& York, A. (2010). Ecological impacts of firewood collection - A literature review to inform firewood management on public land in Victoria. Melbourne: Victorian Government Department of Sustainability and Environment.

Brown, S., Gillespie, A. J. R., \& Lugo, A. E. (1989). Biomass estimation methods for tropical forests with applications to forest inventory data. Forest Science, 35, 881-902.

Chanal, M. (2012). How is $100 \%$ renewable energy possible in South Korea by 2020? (pp. 1-33). Global Energy Network Institute.

Cresswell, J. . (1994). Research design qualitative quantitative and mixed methods approaches. London: Sage. (pp. 3-26). doi:10.3109/08941 939.2012.723954

Department of Forestry. (2005). Fuelwood consumption 2002 - 2004. Jakarta: Centre for Forestry Planning and Statistics, Forestry Planning Agency.

Forestry Act No 41 (1999). Republic of Indonesia.

Goverment Regulation No 28: Management of Nature Reserve Areas and Nature Conservation Areas (2011). Republic of Indonesia.

Johannesen, A. B. (2006). Designing Integrated Conservation and Development Projects (ICDPs): Illegal hunting, Wildlife Conservation, and the Welfare of the Local People. Environment and Development Economics, 11, 247-267.

Lampung Timur's Bureau of Statistics. (2010). Labuban Ratu in numbers 2009/2010. Sukadana: Lampung Timur's Bureau of Statistics.

Ludwig, J. A., \& Reynolds, J. F. (1988). Statistical ecology: A premier of methods and computing. New York: Wiley Press.

Magurran, A. E. (1988). Ecological diversity and its measurement. Princeton: Princeton University Press. 
Mathews, E. (2009). Undying flame: the continuing demand for wood as fuel. World Resource Institute. Retrieved from http://earthtrends. wri.org/text/ energyresources/feature-3.html [01/11/2011]

Mehta, V. K., Sullivan, P. J., Walter, M. ., Krishnaswamy, J., \& DeGloria, S. D. (2008). Ecosystem impacts of disturbance in a dry tropical forest in Southern India. Ecohydrol, 1, 149-160.

Organisation for Economic Co-operation and Development. (2002). World energy outlook.

Sankaran, M., \& McNaughton, S. J. (2005). Terrestrial Plant-herbivore interactions: Integrating across multiple determinants and trophic levels. In M. E (Ed.), Vegetation ecology (pp. 265-285). Malden, USA: Blackwell Publishing.

Simon, H. (1999). Pengelolaan hutan bersama masyarakat. Yogyakarta: Gadjah Mada University Press.

Skutsch, M., \& Ghilardi, A. (2008). Energy Access In REDD: Prospects for socially responsible woodfuel interventions. Centro de Investigacionesen Geografía Ambiental. Morelia, Mexico: UNAM.

Verhoest, C., \& Ryckmans, Y. (2012). Industrial wood pellets report. Laborelec, PellCert, and Intelegent Energy Europe.

Verplanke, J. J., \& Zahabu, E. (2009). A field guide for assessing and monitoring reduced forest degradation and carbon sequestration by local communities. Project team KYOTO: Think Global, Act Local (K: TGAL), Department of Technology and Sustainable Development, University of Twente.

Verschuren, P., \& Doorewaard, H. (2010). Designing a research project. $2^{\text {nd }} E d$. Hague: Eleven International Publishing.

WKNP Authority. (2011). Management plan of forest rehabilitation in WKNP 2012-2016. Labuhan Ratu: WKNP Authority.

Yamane, T. (1967). Elementary sampling theory. Englewood Cliffs: Prentice-Hall Inc. 


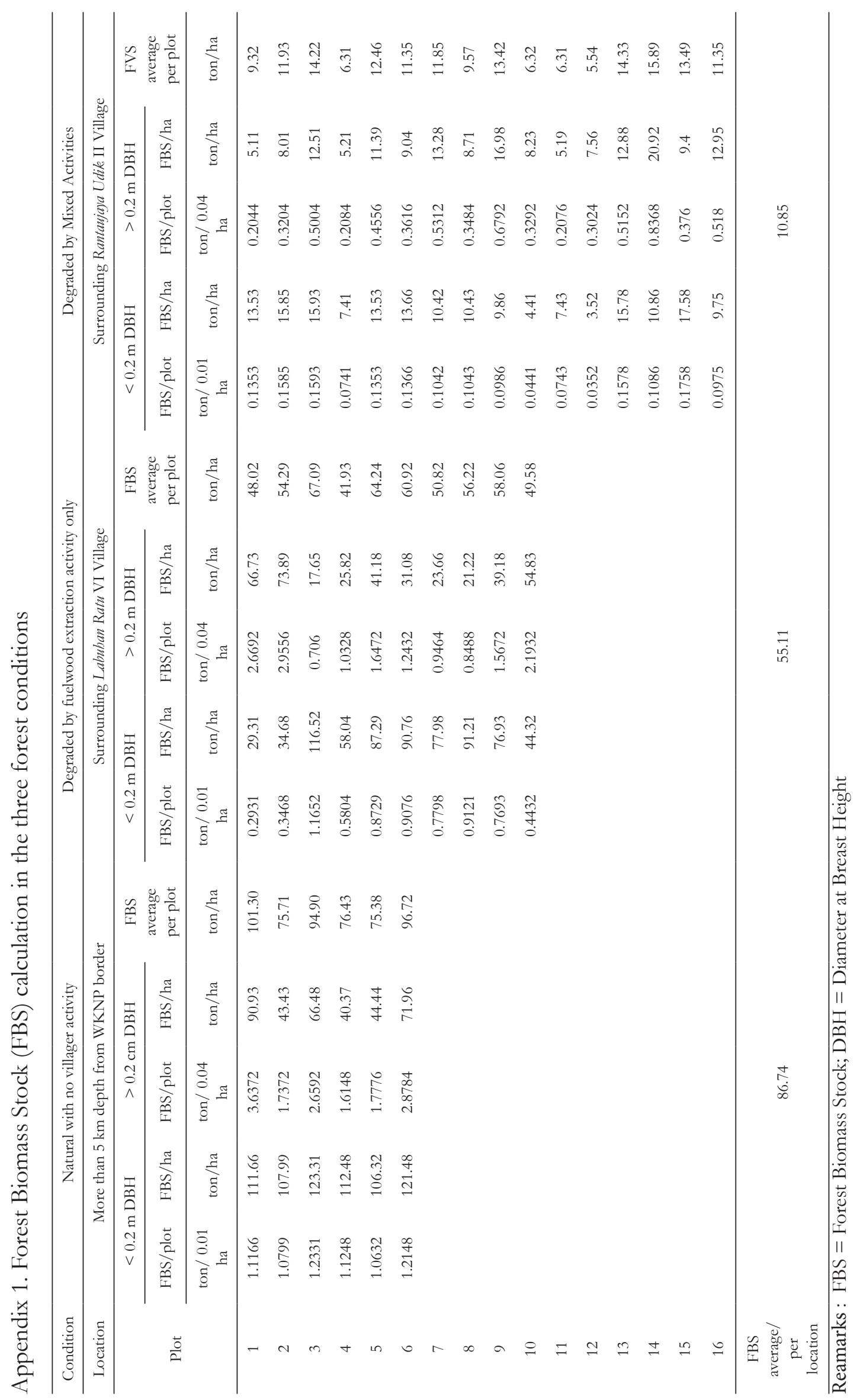

